\title{
Late sequelae of systemic lupus erythematosus in children
}

\section{Późne następstwa tocznia rumieniowatego układowego u dzieci}

\author{
Małgorzata Wierzbowska, Piotr Gietka, Lidia Rutkowska-Sak \\ Department of Developmental Age Rheumatology, Institute of Rheumatology, Warsaw, Poland
}

Key words: juvenile systemic lupus erythematosus, late consequences, SLEDAI index, SLICC/ACR Damage Index for SLE.

Słowa kluczowe: młodzieńczy toczeń rumieniowaty układowy, późne następstwa, indeksy SLEDAI, SLICC/ACR.

\begin{abstract}
Summary
Objectives: Systemic lupus erythematosus classifield as one of the systemic inflammatory diseases of connective tissue, is a classic example of an autoimmune disease. Juvenile systemic lupus erythematosus contributes $5-10 \%$ of all cases of this disease. Based on 20-years follow up, the authors tried to assess the variety of clinical manifestations, course, prognosis and the most common sequelae of the disease in children.

Material and methods: The study involved an analysis of the medical records of 138 patients. All the patients met 4 or more of the American College of Rheumatology Classification Criteria. The group of children was hospitalized in the Institute of Rheumatology in Warsaw from 1985 to 2005. The disease activity at its onset and during its further course was estimated according to the Systemic Lupus Erythematosus Disease Activity Index (SLEDAI) Results: The assessment of the course of the disease in the examined period indicated that considerable improvement, evidenced by significant reduction or resolution of disease activity, was achieved in 85 children, while the disease progressed or remained unchanged despite the treatment in 47 children. Six cases resulted in the death of patients. The most frequent cause of death was sepsis.

Conclusions: The course of SLE in children has changed over the last 20 years. The mortality rate has decreased considerably. Amelioration and remission are more frequent today. The average age of onset has increased by 2 years.

The most frequent cause of death is general infections (previously it was renal failure). Currently the disease activity in the initial stage is lower, according to SLEDAI. In the initial stage of the disease there is a statistically significant decrease of frequency of occurrence of symptoms such as kidney involvement and epilepsy attacks. The increase in frequency of psychosis occurrence and the presence of anti-nDNA antibodies in blood serum is statistically significant.
\end{abstract}

\section{Streszczenie}

Cel pracy: Toczeń rumieniowaty układowy, jedna z układowych chorób tkanki łącznej, jest klasycznym przykładem chorób z autoimmunizacji. Młodzieńczy toczeń rumieniowaty układowy stanowi 5-10\% wszystkich zachorowań na tę chorobę. Autorzy na podstawie 20-letniej obserwacji podjęli próbę analizy dotyczącej zmiany obrazu klinicznego, przebiegu, prognozy oraz późnych następstw choroby u dzieci.

Materiat i metody: Badaniami objęto 138 dzieci. Rozpoznanie choroby ustalono na podstawie kryteriów ACR (American College of Rheumatology); każdy pacjent spełniał co najmniej 4 kryteria. Dzieci były hospitalizowane w Klinice Reumatologii Wieku Rozwojowego Instytutu Reumatologii w Warszawie w latach 1985-2005. Przeprowadzając analizę dotyczącą oceny aktywności na początku choroby i w jej późniejszym przebiegu, zastosowano skalę SLEDAI (Systemic Lupus Erythematosus Disease Activity Index).

Wyniki: Ocena przebiegu choroby w badanym okresie wykazała, że był on łagodniejszy u dzieci, które zachorowały w późniejszym okresie. Poprawę wyrażoną znacznym zmniejszeniem lub ustąpieniem aktywności choroby uzyskano u 85 dzieci, postęp choroby lub utrzymywanie się aktywności pomimo stosowanego leczenia - u 47 dzieci. Sześcioro dzieci zmarło. Najczęstszą przyczyną zgonu była posocznica.

Wnioski: Przebieg choroby zmienit się w ciagu ostatnich 20 lat. Obniżył się znacznie wskaźnik śmiertelności, częściej uzyskuje się poprawę i remisję choroby. Średni wiek zachorowania ulegt podwyższeniu mniej więcej o 2 lata.

Najczęstszą przyczyną zgonów są obecnie uogólnione infekcje (we wcześniejszych latach była to niewydolność nerek). Zmniejszyła się początkowa aktywność choroby oceniana w skali SLEDAl. Istotnej statystycznie zmianie uległa też częstość występowania niektórych objawów na początku choroby: rzadziej obserwuje się zajęcie nerek i padaczkę, częściej psychozy i obecność przeciwciał przeciw natywnemu DNA.

\section{Address for correspondence:}

Prof. Lidia Rutkowska-Sak, MD, PhD, DSc, Department of Developmental Age Rheumatology, Institute of Rheumatology, Spartańska 1, 02-637 Warsaw, Poland, e-mail: lidia.rutkowska@ir.ids.pl

Submitted: 5.06.2014 


\section{Introduction}

Systemic lupus erythematosus (SLE) is a multi-system autoimmune disease of unknown etiology, characterized by vasculitis and high serum antibody levels. Due to the possibility of developing inflammation in any organs and systems of the human body, the clinical presentation may vary, and the course of the disease as well as its prognosis is difficult to predict [1-3]. Untreated, SLE is progressive and the prognosis is poor.

Recent study results have contributed to a better understanding of SLE etiology and to developing both more effective forms of therapy and the means of counteracting the late sequelae of the disease.

\section{Aim of the study}

The aim of this study was to assess the variety of its clinical manifestations and the course of juvenile systemic lupus erythematosus (jSLE) in children diagnosed with jSLE over a period of two decades. Another aim of the study was to identify the most common late sequelae of the disease, defined as irreversible anatomical and/or functional organ damage resulting from previous jSLE activity and persisting for at least 6 months.

\section{Material and methods}

A total of 138 children, i.e. 19 boys (13.8\%) and 119 girls (86.2\%), hospitalized in the Department of Developmental Age Rheumatology at the Institute of Rheumatology in Warsaw in the period between 1985 and 2005 , were included in the study. The mean age of onset was $7.9 \pm 0.2$ years, and the mean follow-up period was $8.86 \pm 0.39$ years.

The diagnosis was established based on the 1997 revised American College of Rheumatology (ACR) criteria.

An analysis of late sequelae of jSLE was conducted based on the Damage Index for SLE developed by the Systemic Lupus International Collaborating Clinics and American College of Rheumatology (SLICC/ACR) [4, 5].

Disease activity was assessed via the Systemic Lupus Erythematosus Disease Activity Index (SLEDAI) $[6,7]$, with points from 1 to 8 assigned to individual clinical and immunological features. The SLEDAl includes most of the ACR diagnostic criteria for SLE and other additional clinical and immunological features of this disease.

\section{Calculation methods}

The range of variability, mean values, and errors of quantitative variables, such as: age, year of onset, and SLEDAI, were calculated from the normal distribution. The incidence and errors of qualitative variables, such as the occurrence of individual symptoms, were calculated from the binomial distribution. Correlation coefficients between the year of onset and other parameters were also calculated. In the case of those parameters whose correlation coefficients were statistically significant, linear correlation for the incidence of the given parameter in year-of-onset intervals was determined. The year-of-onset intervals were selected in such a way that each one contained attainably equal numbers of patients. The results with the $p$ value $<0.05$ were considered to be statistically significant, while $p<0.1$ showed a trend towards significance.

\section{Results}

Initial disease activity was assessed with the SLEDAI. High scores - above 20 points - were found in 90 children (65.2\%), intermediate scores - from 10 to 19 points - in 33 children (23.9\%), and low scores - below 10 points - in 15 children (10.9\%). An assessment of the course of the disease in given periods of time showed that 85 children (61.6\%) achieved improvement in terms of significant reduction or cessation of disease activity, whereas 47 children (34.1\%) experienced disease progression or persistently active disease despite treatment.

Six deaths were observed, yielding the mortality rate of $4.3 \%$. The most common cause of death was generalized infection - sepsis with disseminated intravascular coagulation (DIC) (3 children; 50\%). Other causes of death were renal failure, suicide, and a sudden death without discernible cause (1 child each; 16.6\%).

Tables I and II present the results of a statistical analysis stratified by the baseline rates of occurrence of the clinical and immunological markers evaluated in ACR diagnostic criteria and SLEDAI, respectively.

The statistical analysis revealed changes in the following parameters with respect to the year of onset: age of onset, SLEDAI score, and disease severity including mortality rate.

Figure 1 shows the correlation between the age of jSLE onset and the calendar year of onset. The graph demonstrates a delay in the age of jSLE onset over time. After the year 2000, the mean age of onset was higher by 2 years in comparison to that in the previous years.

Figure 2 presents the correlation of SLEDAI score and the calendar year of jSLE onset. The graph demonstrates baseline disease activity (SLEDAI) diminishing in subsequent calendar years after the onset of the disease.

Figure 3 presents jSLE severity measured by the number of flares and deaths stratified by the year of onset. The graph demonstrates that jSLE severity was milder in children who developed SLE after 1996. No deaths were 
Table I. Rate of occurrence of ACR parameters

\begin{tabular}{|c|c|c|c|}
\hline Parameter & $n$ & $\%$ & Error \\
\hline $\begin{array}{l}\text { Presence of anti-nuclear } \\
\text { antibodies (ANA) }\end{array}$ & 134 & 90.1 & 1.4 \\
\hline Malar ("butterfly") rash & 116 & 84.1 & 3.1 \\
\hline Arthritis & 116 & 84.1 & 3.1 \\
\hline Leukopenia & 81 & 58.7 & 4.2 \\
\hline Renal disease & 66 & 47.8 & 4.3 \\
\hline $\begin{array}{l}\text { Presence of anti-nDNA } \\
\text { antibodies }\end{array}$ & 65 & 47.1 & 4.2 \\
\hline Thrombocytopenia & 43 & 31.2 & 3.9 \\
\hline Presence of anti-Sm antibodies & 39 & 28.3 & 3.8 \\
\hline Epilepsy & 34 & 24.0 & 3.7 \\
\hline Photosensitivity & 29 & 21.0 & 3.5 \\
\hline Pericarditis & 26 & 18.8 & 3.3 \\
\hline Oral ulcers & 20 & 14.5 & 3.0 \\
\hline Pleurisy & 16 & 11.6 & 2.7 \\
\hline Hemolytic anemia & 16 & 11.6 & 2.7 \\
\hline LE cells & 16 & 11.6 & 2.7 \\
\hline False-positive syphilis test & 15 & 10.9 & 2.6 \\
\hline Psychoses & 5 & 3.6 & 1.6 \\
\hline Discoid lupus & 0 & 0 & 0.7 \\
\hline
\end{tabular}

observed in this group of patients. The differences were statistically significant.

Moreover, certain clinical and immunological features were also observed to change depending on the year of onset. This is presented in Table III and Figures 4 a-e.

The analyses presented above demonstrate lower rates of proteinuria and epileptic seizures as well as higher rates of psychoses and hemolytic anemia in children who developed SLE in later years. This group of children

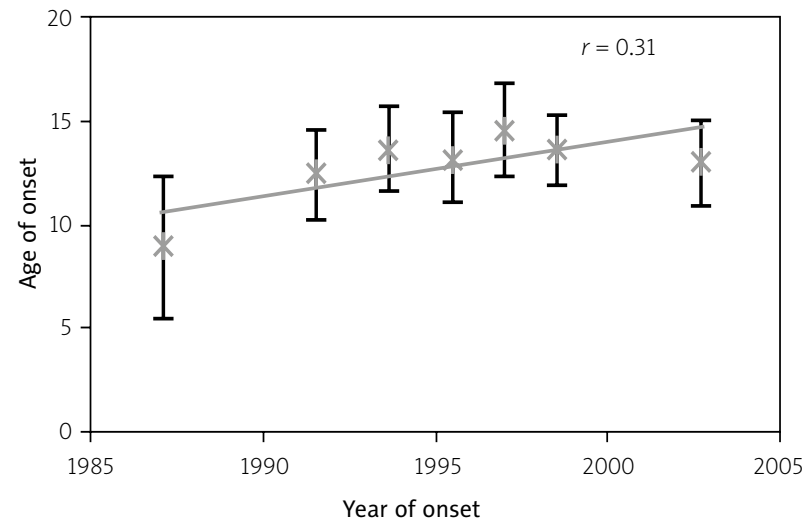

Fig. 1. Correlation between age of onset and the year of onset.
Table II. Rate of occurrence of SLEDAI descriptors

\begin{tabular}{|lccc|}
\hline Descriptors & $n$ & $\%$ & Error \\
\hline Arthritis & 116 & 84.1 & 3.1 \\
\hline Skin rash & 116 & 84.1 & 3.1 \\
\hline Low complement & 112 & 81.2 & 3.3 \\
\hline Fever & 99 & 71.7 & 3.8 \\
\hline Leukopenia & 81 & 58.0 & 4.2 \\
\hline Proteinuria & 66 & 47.8 & 4.3 \\
\hline $\begin{array}{l}\text { Presence of anti-nDNA } \\
\text { antibodies }\end{array}$ & 65 & 47.1 & 4.2 \\
\hline Microscopic hematuria & 61 & 44.2 & 4.2 \\
\hline Vasculitis & 59 & 42.8 & 4.2 \\
\hline Leukocyturia & 54 & 39.1 & 4.2 \\
\hline Urinary casts & 53 & 38.4 & 4.1 \\
\hline Thrombocytopenia & 43 & 31.2 & 3.9 \\
\hline Nervous system involvement & 41 & 29.7 & 3.9 \\
\hline Alopecia & 32 & 23.2 & 3.6 \\
\hline Pericarditis & 26 & 18.3 & 3.3 \\
\hline Mucosal ulcers & 20 & 14.5 & 3.0 \\
\hline Pleurisy & 16 & 11.6 & 2.7 \\
\hline Myositis & 16 & 11.6 & 2.7 \\
\hline
\end{tabular}

was also characterized by higher rates of anti-nDNA antibodies in their immunological tests.

The evaluated patients were also followed-up for sequelae, defined as irreversible anatomical or functional organ damage resulting from previous jSLE activity and persisting for over 6 months.

This analysis was conducted using the of SLICC/ACR Damage Index for SLE, and its results are presented in Table IV.

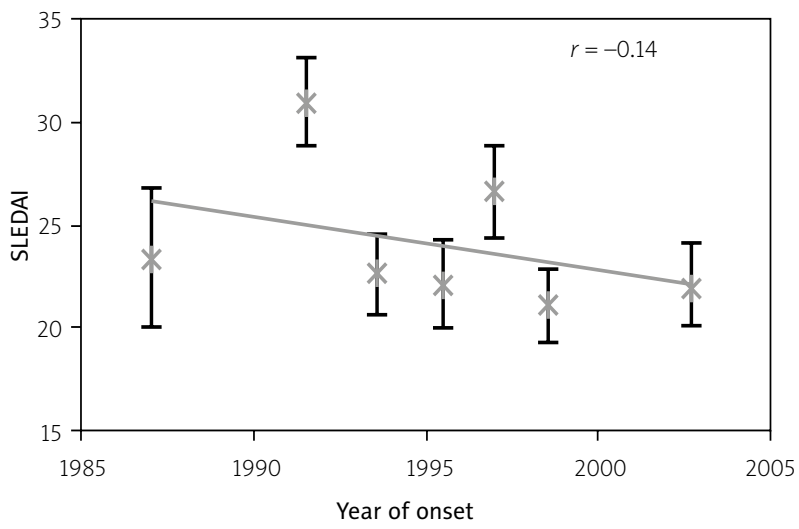

Fig. 2. Correlation between jSLE activity (SLEDAI) and year of onset. 


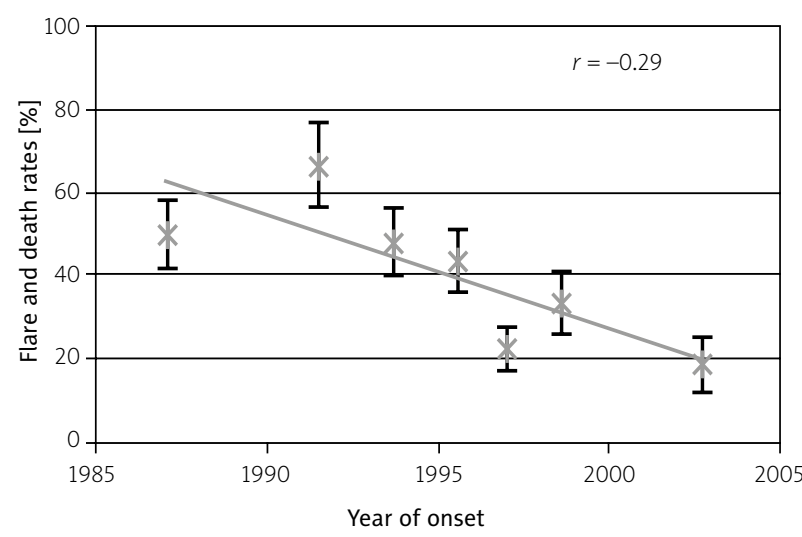

Fig. 3. Correlation between disease severity and year of onset.

The most common late sequelae of jSLE were renal, CNS, and recurrent vascular involvement. Renal involvement was defined as persistent proteinuria > $0.5 \mathrm{~g} /$ day or glomerular filtration rate $<50 \%$ (SLICC/ACR Damage Index for SLE). Two of the evaluated children developed end-stage renal disease and underwent subsequent renal transplantation.

The most commonly observed late neuropsychiatric sequelae were epileptic seizures ( 5 children) and mental disturbances (4 children); while chorea (3 patients), persistent headaches ( 2 patients), and transverse myelitis (1 child) were less common.

Peripheral vascular involvement most commonly resulted from secondary antiphospholipid syndrome (9 patients).

Recurrent malar rash was observed in 5 patients, with alopecia and recurrent non-specific macular rashes observed less commonly.

Ocular sequelae were observed in 3 patients and included 2 cases of poststeroid cataract and 1 case of central retinal artery occlusion. Recurrent bouts of arthritis resulted in Jaccoud arthropathy development.

One patient developed acute pancreatitis, and another one developed chronic interstitial pulmonary fibrosis.

The correlation between organ damage and the calendar year of onset was assessed (Table V).

A 20-year follow-up revealed no statistically significant differences in terms of late sequelae of jSLE however, a clear trend toward reduced rates of renal involvement, ocular involvement, and recurrent infections was observed.

\section{Discussion}

The prognosis in jSLE has improved considerably over the last several decades [7-11]. This was partly due to upgraded diagnostic and therapeutic methods (the
Table III. Correlation between rate of occurrence of jSLE manifestations and year of onset

\begin{tabular}{|lc|}
\hline Clinical and immunological features of jSLE & $\begin{array}{c}\text { Correlation } \\
\text { coefficient }(r)\end{array}$ \\
\hline Malar rash & 0.00 \\
\hline Photosensitivity & 0.09 \\
\hline Oral ulceration & 0.08 \\
\hline Arthritis & -0.07 \\
\hline Pleurisy & -0.04 \\
\hline Pericarditis & -0.03 \\
\hline Proteinuria & -0.18 \\
\hline Seizures & -0.18 \\
\hline Psychoses & 0.19 \\
\hline Hemolytic anemia & 0.15 \\
\hline Leukopenia & -0.01 \\
\hline Thrombocytopenia & 0.08 \\
\hline LE cells & -0.05 \\
\hline Anti-nDNA antibodies & 0.20 \\
\hline Anti-Sm antibodies & 0.10 \\
\hline False-positive syphilis tests & -0.17 \\
\hline$p<0.05-$ statistically significant difference & \\
\hline$<0.1-$ trend &
\end{tabular}

use of very high doses of glucocorticoids in combination with cytostatics) and the use of dialyses during acute lupus nephropathy. Our own observations suggested that a vast majority of children achieved remission following treatment, and despite occasional flares the mortality rate decreased significantly.

Despite the observed improvement in SLE prognosis, jSLE patients may develop late organ damage, not only as a consequence of the long-term disease, but also as a complication associated with the use of glucocorticoids and immunosuppressive drugs [12].

The evaluated material showed that the age of onset increased over the period of 20 years and after the year 2000 the mean age at onset was approximately 2 years higher than that in the 1980's, whereas the general disease activity was lowered, and the course of jSLE was milder. There were no deaths in the group of children who developed SLE after 1996, which seems to be favorable from a prognostic point of view. The observed differences were statistically significant.

A long-term University of California follow-up study (including 957 adults with jSLE, 98 of whom developed the disease in childhood) revealed that childhood onset of SLE is a strong predictor of poor prognosis and early mor- 


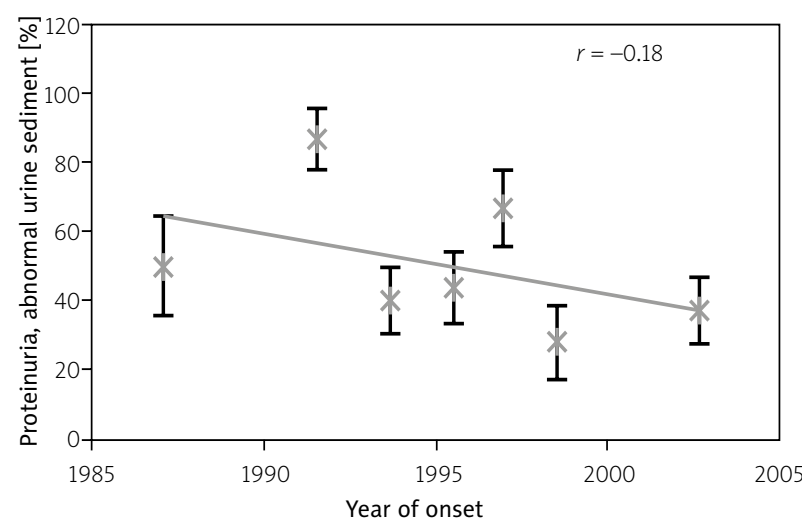

Fig. 4a. Correlation between rate of occurrence of proteinuria and year of SLE onset.

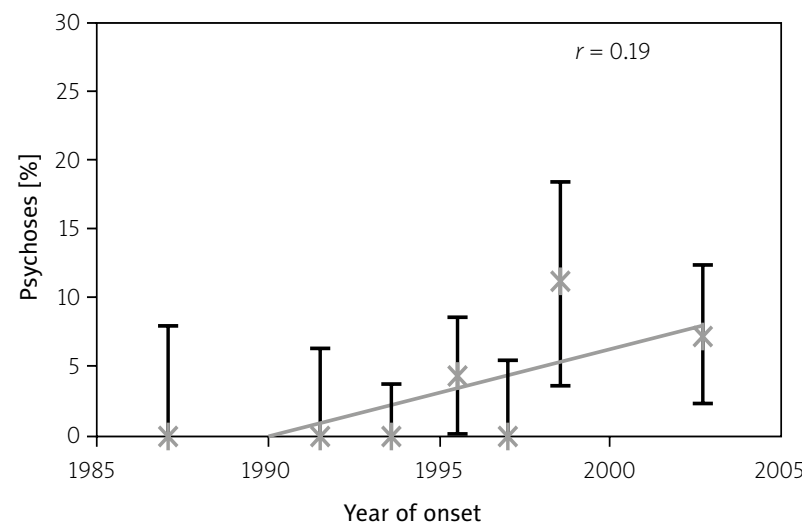

Fig. 4c. Correlation between rate of occurrence of psychoses and year of SLE onset.

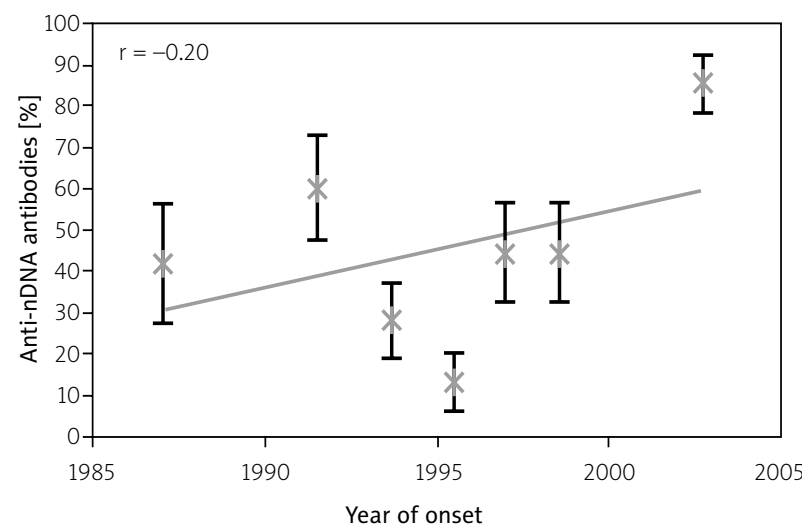

Fig. 4e. Correlation between rate of occurrence of anti-native-DNA antibodies and year of SLE onset.

tality [13]. Studies conducted in Cleveland also revealed a persistent significant mortality among jSLE patients in comparison to that observed over the previous years [14].

In this study, the analysis also demonstrated a changed incidence of various clinical and immunological manifestations.

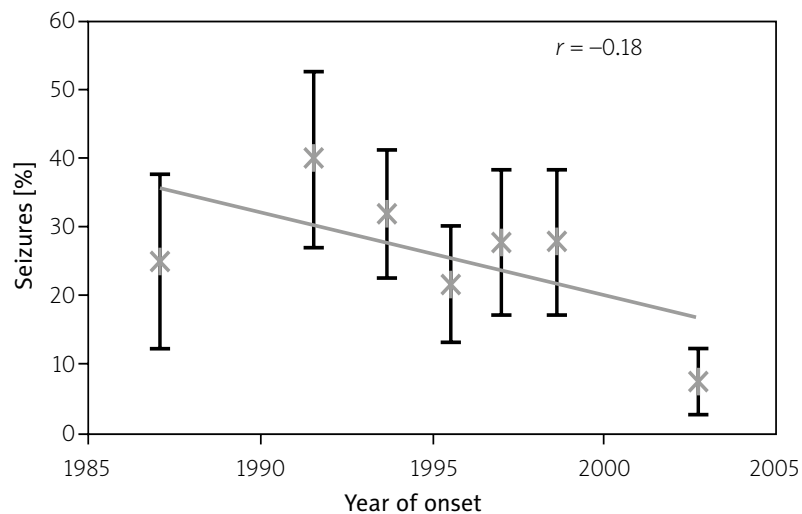

Fig. 4b. Correlation between rate of occurrence of seizures and year of SLE onset.

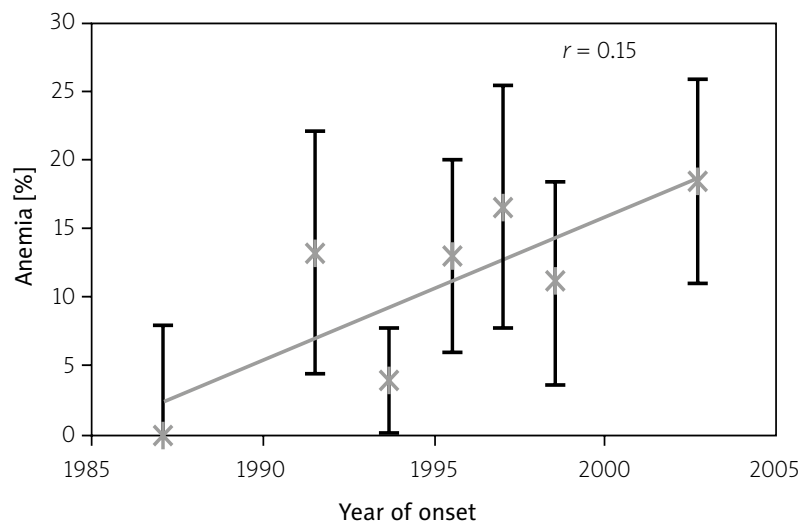

Fig. 4d. Correlation between rate of occurrence of hemolytic anemia and year of SLE onset.

Children who developed SLE in later years rarely exhibited proteinuria and seizures, while being more often affected by psychoses and more often presenting anti-nDNA antibodies in immunological tests; at the same time, showing a trend toward a greater incidence of hemolytic anemia.

The most common late sequelae of jSLE included renal abnormalities (in 16.7\% of children) and CNS involvement (in $11.4 \%$ of children).

Other authors have also reported CNS involvement and cognitive dysfunction as common occurrences. More specifically, investigators from a psychiatric hospital in Toronto evaluated 53 children in the period between 1985 and 2009. All children were shown to have cognitive dysfunction and $75 \%$ of them - psychotic dysfunction [15].

Other authors reported that neuropsychiatric manifestations of jSLE can be detected in up to $20-51 \%$ of patients, and CNS abnormalities are among the most common causes of death. The most commonly observed signs and symptoms included headaches, cognitive dysfunction, mood disorders, and convulsions [16].

A group of American physicians who examined 49 children with jSLE via magnetic resonance imaging 
Table IV. Late sequelae of juvenile systemic lupus erythematosus

\begin{tabular}{|lccc|}
\hline Parameter & $n$ & $\%$ & Error \\
\hline Renal involvement & 23 & 16.7 & \pm 3.2 \\
\hline $\begin{array}{l}\text { Central nervous system } \\
\text { involvement }\end{array}$ & 15 & 11.4 & \pm 2.8 \\
\hline Vascular involvement & 11 & 8.0 & \pm 2.3 \\
\hline Skin rash & 8 & 5.8 & \pm 2.0 \\
\hline Thrombocytopenia & 4 & 2.9 & \pm 1.4 \\
\hline Visual disturbances & 3 & 2.2 & \pm 1.2 \\
\hline Recurrent infections & 2 & 1.4 & \pm 1.0 \\
\hline Musculoskeletal involvement & 2 & 1.4 & \pm 1.0 \\
\hline Diabetes mellitus & 1 & 0.7 & \pm 0.7 \\
\hline Pulmonary involvement & 1 & 0.7 & \pm 0.7 \\
\hline Gastrointestinal involvement & 1 & 0.7 & \pm 0.7 \\
\hline
\end{tabular}

concluded that a majority of children and adolescents exhibit lower cerebral and cerebellar volumes associated with neuronal deficits, thin corpus callosum, and ventricular enlargements. These changes were observed prior to glucocorticoid treatment introduction and their severity has been shown to depend neither on the treatment nor on disease duration [17].

Musculoskeletal involvement in the analyzed group of patients was observed in two patients in the form of recurrent bouts of arthritis, which resulted in development of Jaccoud arthropathy. According to other authors, it is osteoporosis that is the most common cause of skeletal damage [18]. In the case of osteoporosis, glucocorticoid treatment should be considered as its potential cause (glucocorticoid-induced osteoporosis [GIO]).

No cases of cancer were observed in the study group; however, other authors reported neoplastic disease in children treated for jSLE in retrospective studies. The studies were conducted in 10 pediatric medical centers. The course of the disease was analyzed in a large group of 1,020 children from 1974 to 2009. During that period, 14 cases of solid carcinoma, 1 case of leukemia, and 2 cases of lymphoma were diagnosed in the evaluated group. The study results suggest an increased risk of malignant neoplasms in jSLE patients aged between 10 and 19 versus the general population [19]. We did not observe such correlation in our study.

No cardiac abnormalities were observed in the evaluated study group; no serious menstruation disturbances were observed in women over the course of their jSLE.

Many authors have reported a correlation between a high incidence of organ damage in jSLE and high disease activity in the early stages of the disease [20, 21]
Table V. Correlation coefficients between jSLE sequelae and the year of onset

\begin{tabular}{|lc|}
\hline jSLE sequelae & Correlation coefficient \\
\hline Ocular involvement & -0.15 \\
\hline $\begin{array}{l}\text { Central nervous system } \\
\text { involvement }\end{array}$ & 0.00 \\
\hline Renal involvement & -0.15 \\
\hline Pulmonary involvement & 0.09 \\
\hline Vasculitis & -0.06 \\
\hline Gastrointestinal involvement & 0.02 \\
\hline Musculoskeletal involvement & -0.11 \\
\hline Skin involvement & -0.02 \\
\hline Diabetes mellitus & -0.08 \\
\hline Recurrent infections & -0.18 \\
\hline Thrombocytopenia & -0.04 \\
\hline
\end{tabular}

This trend can also be observed in the evaluated group. High initial jSLE activity is an unfavorable prognostic factor, which has also been confirmed in other studies. This makes early diagnosis of the most active cases of jSLE in children very important, and aggressive immunosuppressive treatment must be introduced as soon as possible in patients with SLEDAI of over 20 points.

\section{Conclusions}

1. The course of SLE in children has changed over the last 20 years.

2. The mortality rate has significantly decreased and improvement or remission are more commonly achieved.

3. The mean age of onset has increased by 2 years.

4. Generalized infections currently constitute the most common cause of death (whereas previously this was renal failure).

5. Currently, the initial jSLE SLEDAI is lower.

6. A statistically significant reduction in the incidence of renal involvement and seizures can be currently observed.

7. There was a statistically significant increase in the incidence of psychosis and the presence of serum antinDNA antibodies.

8. A trend toward increasing incidence of hemolytic anemia has been observed.

9. The most common late sequelae of the disease were renal abnormalities, CNS involvement, vascular involvement, and persistent skin lesions.

The authors declare no conflict of interest. 


\section{References}

1. Cassidy JT, Petty RE. Texbook of Pediatric Rheumatology. Third Edition 1995: 1-260.

2. Tan EM, Cohen AS, Fries JF, et al. The 1982 revised criteria for the classification of systemic lupus erythematosus. Arthritis Rheum 1982; 25: 1271-1277.

3. Romicka AM. Wybrane zagadnienia z tocznia rumieniowatego uogólnionego w wieku rozwojowym. Ped Pol 1994; 49: 1037.

4. Urowitz MB, Gladman DD. Assessment of disease activity and damage in SLE. In: Bailleiere's clinical rheumatology. International practise and research, Gladman DD, Hochberg MC (eds.). Bailliere Tindall, London 1998; 405-413.

5. Gladman D, Ginzler E, Golsmith C, et al. Systemic lupus international collaborative clinics: development of a damage index in systemic lupus erythematosus. J Rheumatol 1992; 19: 1820-1821.

6. Bombardier C, Gladman DD, Urovitz M, et al. Derivation of the SLEDAI. A disease activity index for lupus patients. Arthritis Rheum 1992; 35: 630-640.

7. McLaughin J, Glodman DD, Urovitz M. Kidney biopsy in systemic lupus erythematosus. II. Survival analysis according to biopsy results. Arthritis Rheum 1991; 34: 1268-1273.

8. Austin HA, Muenz LR, Joyce KM. Prognostic factors in lupus nephritis. Contribution of renal histologic data. Ann J Med 1983; 75: 382-391.

9. Ginzler EM, Schron K. Outcome and prognosis in SLE. Rheum Dis Clin North Am 1988; 14: 67-78.

10. Mok CC, Wong RWS, Lai KN. Treatment of severe proliferative lupus nephritis: the current state. Ann Rheum Dis 2003; 62: 799-804.

11. Wierzbowska M, Rostropowicz-Denisiewicz K, Romicka AM. Clinical course, prognostic factors in juvenile systemic lupus erythematosus. Progress in Rheumatology, Israel 1999; 7: 18.

12. Barron KS, Silverman ED, Gonzales J, et al. Clinical serologic and immunogenetic sudies in childhood - onset systemic lupus erythematosus. Arthritis Rheum 1993; 36: 348-354.

13. Hersh AO, Trupin L, Yazdany J, et al. Childhood-onset disease as a predictor of mortality in an adult cohort of patients with systemic lupus erythematosus. Arthritis Care Res (Hoboken) 2010; 62: 1152-1159.

14. Hashkes PJ, Wright BM, Lauer MS, et al. Mortality outcomes in pediatric rheumatology in the US. Arthritis Rheum 2010; 62: 599-608.

15. Lim LS, Lefebvre A, Benseler S, et al. Psychiatric illness of systemic lupus erythematosus in childhood: spectrum of clinically important manifestations. J Rheumatol 2013; 40: 506-512.

16. Fernandes H, Brito I. Juvenile Systemic Lupus Erythematosus: neuropsychiatric manifestations. Acta Reumatol Port 2012; 37: 117-125.

17. Muscal E, Traipe E, de Guzman MM, et al. Cerebral and cerebellar volume loss in children and adolescents with systemic lupus erythematosus: a review of clinically acquired brain magnetic resonance imaging. J Rheumatol 2010; 37: 1768-1775.

18. Gladman DD, Urowitz MB, Rahman P, et al. Accrual of organ damage over time in patients with systemic lupus erythematosus. J Rheumatol 2003; 30: 1955-1959.

19. Bernatsky S, Clarke AE, Labrecque J, et al. Cancer risk in childhood-onset systemic lupus. Arthritis Res Ther 2013; 15: R198.
20. Stoll T, Seifert B, Isenberg A. SLICC/ACR damage index is valid, and renal and pulmonary organ scores are predictors of severe outcome in patients with systemic lupus erythematosus. Br J Rheumatol 1996; 35: 248-254.

21. Gladman D, Goldsmith C, Urowitz M, et al. Derivation of a weighting scale for the SLICC/ACR damage index - preliminary results. Arthritis Rheum 1994; 37 (suppl 9): S326 (abstract 994). 